Supporting information

\title{
Unambiguous and controlled one pot synthesis of multifunctional silica nanoparticles
}

Jeremie Ciccione, ${ }^{1,2 \ddagger}$ Tao Jia, ${ }^{3 \ddagger}$ Jean-Luc Coll, ${ }^{3}$ Karine Parra, ${ }^{1}$ Muriel Amblard, ${ }^{1}$ Said Jebors, ${ }^{1,2}$ Jean Martinez ${ }^{1}$, Ahmad Mehdi ${ }^{2} *$ and Gilles Subra ${ }^{1}$ *

${ }^{1}$ Institut des Biomolécules Max Mousseron (IBMM), UMR5247 CNRS, ENSCM, Université de Montpellier, 15 avenue Charmes Flahault 34093 Montpellier Cedex 05, France

${ }^{2}$ Institut Charles Gerhardt (ICG), UMR5253 CNRS, ENSCM, Universite 'de Montpellier, Equipe Chimie Moléculaire et Organisation du Solide, Place Eugène Bataillon, 34095 Montpellier Cedex 05, France

${ }^{3}$ Institut Albert Bonniot IAB INSERM/UJF U823, Université Joseph Fourier, La Tronche, France.

Table of contents:

$\begin{array}{ll}\text { Abbreviations } & \text { P.3 }\end{array}$

$\begin{array}{ll}\text { General experimental and synthetic procedures } & \text { P.3 }\end{array}$

$\begin{array}{ll}\text { Synthesis of hybrid peptides and experimental protocols } & \text { P.5 }\end{array}$

$\begin{array}{ll}\text { Figure S1. Synthesis of hybrid triethoxysilyl fluorescein } 1 & \text { P.10 }\end{array}$

$\begin{array}{ll}\text { Figure S2. LC/MS analysis of fluorescein precursor solution } & \text { P.10 }\end{array}$

$\begin{array}{ll}\text { Figure S3. TEM images of unfunctionnalized fluorescent nanoparticles } & \text { P.11 }\end{array}$

Figure S4. Size distribution of unfunctionnalized fluorescent nanoparticles

$\begin{array}{ll}\text { measured by the DLS technique } & \text { P.12 }\end{array}$

Figure S5. TEM analysis of functionnalized fluorescent nanoparticles $\mathrm{Np}^{25} 5 / 5 \quad$ P.12

Figure S6. Synthesis of hybrid peptide 2 cyclic $\left[\mathrm{Lys}\left[(\mathrm{EtO})_{3} \mathrm{Si}\left(\mathrm{CH}_{2}\right)_{3} \mathrm{NHCO}-[\beta \mathrm{Ala}]_{4}-\right] \mathrm{Arg}-\right.$

$\begin{array}{ll}\text { Gly-Asp-(D)Phe] } & \text { P.13 }\end{array}$

$\begin{array}{ll}\text { Figure S7. LC/MS analysis of hybrid peptide } 2 & \text { P.14 }\end{array}$

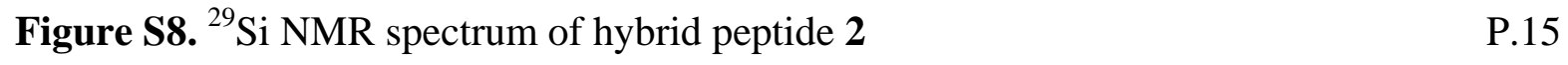

$\begin{array}{ll}\text { Figure S9. LC/MS analysis of hybrid peptide } 3 & \text { P.16 }\end{array}$ 
Figure S10. Synthesis of hybrid peptide 4

Figure S11. LC/MS analysis of hybrid peptide 4

Figure S12. ${ }^{29} \mathrm{Si}$ NMR spectrum of hybrid peptide 4

Figure S13. LC/MS analysis of hybrid peptide 5

Figure S14. ${ }^{19} \mathrm{~F}$ NMR spectrum of $\mathrm{NP}_{\mathrm{F}}{ }^{10}{ }^{100 / 0}$

Figure S15. ${ }^{19} \mathrm{~F}$ NMR spectrum of $\mathrm{NP}_{\mathrm{F}}{ }^{10} 75 / 25$

Figure S16. ${ }^{19} \mathrm{~F}$ NMR spectrum of $\mathrm{NP}_{\mathrm{F}}{ }^{10}{ }^{50 / 50}$

Figure S17. ${ }^{19} \mathrm{~F}$ NMR spectrum of $\mathrm{NP}_{\mathrm{F}}{ }^{10}{ }^{25 / 75}$

Figure S18. ${ }^{19} \mathrm{~F}$ NMR spectrum of $\mathrm{NP}_{\mathrm{F}}{ }^{10} 0 / 100$

Figure S19. TGA curves of respectively $\mathrm{Np}_{0 / 0}$ and $\mathrm{Np}^{10}{ }_{5 / 5}$

Figure S20. FACS experiments of $\mathrm{NP}^{\mathrm{x}}$ on HUVEC cells line

Figure S21. FACS experiments of $\mathrm{NP}_{\mathrm{F}}{ }^{10}$ on MDA-MB-231 and $\mathrm{H} 358$ cells line

Figure S22. Temporal evolution of hydrodynamic size of nanoparticles measured in cell media (PBS) by the DLS technique.

Table S1. Characterization of multifunctional NPs 


\section{Abbreviations}

ESI-MS, electrospray ionization mass spectrometry; HPLC, High Performance Liquid Chromatography; LC-MS, Tandem Liquid Chromatography/ Mass Spectroscopy. Other abbreviations used were those recommended by the IUPAC-IUB Commission (Eur. J. Biochem. 1984, 138, 9-37).

\section{General experimental and synthetic procedures}

The 2-chorotrityl chloride resin (100-200 Mesh, $1.55 \mathrm{mmol} / \mathrm{g} \mathrm{Cl} / \mathrm{g}$ resin) was purchased from Iris Biotech, stored at $4^{\circ} \mathrm{C}$ and dried under vacuum at least 24 hours before use. Protected amino acids and BOP were purchased from Iris Biotech, Senn Chemicals and Bachem. Fmoc3,3,3 trifluoro (D/L) alanine and Fmoc-3 fluoro (L) phenylalanine was purchased from Polypeptides.

All reagents and solvents were from AlfaAesar, Acros, Sigma-Aldrich or Merck and were used without further purification.

\section{LC/MS analyses}

Samples for LC/MS analyses were prepared in acetonitrile/water (50:50, v/v) mixture, containing $0.1 \%$ TFA. The LC/MS system consisted of a Waters Alliance 2695 HPLC, coupled to a Water Micromass ZQ spectrometer (electrospray ionization mode, ESI-). All the analyses were carried out using a Phenomenex Onyx, 25 x $4.6 \mathrm{~mm}$ reversed-phase column. A flow rate of $3 \mathrm{~mL} / \mathrm{min}$ and a gradient of $(0-100) \% \mathrm{~B}$ over $2.5 \mathrm{~min}$ were used. Eluent $\mathrm{A}$ : water/0.1\% $\mathrm{HCO}_{2} \mathrm{H}$; eluent $\mathrm{B}$ : acetonitrile/0.1\% $\mathrm{HCO}_{2} \mathrm{H}$. Electrospray mass spectra were acquired at a solvent flow rate of $200 \mu \mathrm{L} / \mathrm{min}$. Nitrogen was used for both the nebulizing and drying gas. The data were obtained in a scan mode ranging from 100 to $1000 \mathrm{~m} / \mathrm{z}$ or 250 to $1500 \mathrm{~m} / \mathrm{z}$ to in $0.7 \mathrm{sec}$ intervals; 6 scans were summed up to get the final spectrum.

\section{RP-HPLC Purification}

Preparative chromatographic purification was performed using Waters HPLC 4000 instrument, equipped with a UV detector 486 and Waters Delta-Pack 40×100 mm, $100 \AA$, 15 $\mu \mathrm{m}, \mathrm{C}_{18}$ reversed-phase column using a flow rate of $50 \mathrm{~mL} / \mathrm{min}$. Solvents employed were $0.1 \%$ aqueous TFA and $0.1 \%$ TFA in ACN. 


\section{Dynamic Light Scattering}

The size and size distribution of particles were measured using Nano ZS zetasizer system (Malvern Instruments). Measurement parameters were as follows: a laser wavelength of $633 \mathrm{~nm}$, a scattering angle of $173^{\circ}$, a measurement temperature of $25^{\circ} \mathrm{C}$, a medium refractive index of 1.330 and material refractive index of 0.200 . Before DLS measurement, the nanoparticles was diluted in $\mathrm{H}_{2} \mathrm{O}$ at a concentration of $1 \mathrm{mg} / \mathrm{mL}$, the solution was passed through $0.45 \mu \mathrm{m}$ polyvinylidene fluoride (PVDF) membrane. The sample was loaded into quartz microcuvette and three measurements were performed. The morphologies and dimensions of the samples were revealed with a JEOL 1200 EXII field-emission scanning electron microscope operating at $120 \mathrm{kV}$. Liquid-phase NMR spectra were recorded at room temperature on a BRUKER AVANCE III $600 \mathrm{MHz}\left({ }^{29} \mathrm{Si}\right.$ and $\left.{ }^{19} \mathrm{~F}\right)$ spectrometer. Elemental analysis was performed at the "laboratoire de measures physiques, LMP" University of Montpellier, France. Thermogravimetric analysis (TGA) was performed on a Perkin Elmer TGA6 instrument between 30 and $800{ }^{\circ} \mathrm{C}$ at a heating rate of $15^{\circ} \mathrm{C} \cdot \mathrm{min}^{-1}$ under air.

\section{NMR measurement}

${ }^{19} \mathrm{~F}$ NMR spectra were acquired in $1.5 \mathrm{M} \mathrm{NaOD} / \mathrm{D}_{2} \mathrm{O}$ solution containing $10 \mathrm{mM}$ TFA at 25 ${ }^{\circ} \mathrm{C}$ on a Bruker AVANCE $600 \mathrm{MHz}$ NMR spectrometer equipped with BBFO probe and controlled by TOPSPIN 2.1. TFA was chosen as an external standard for it desired signal resolution and adequate solubility properties. 


\section{Synthesis of hybrid peptides and experimental protocols}

\section{Protocol 1}

(i) Fmoc-Gly-OH (3 eq), DIEA (6 eq), DCM anh., 6 h, rt; SPPS: (ii): deprotection: Pip/DMF (20/80) and (iii) coupling: Fmoc-AA-OH (3 eq), BOP (3 eq), DIEA (6 eq), DMF, rt; (iv) TFEAcOH-DCM (20:10:70, v/v/v), 1h, rt. (v) DIEA (3 eq), BOP (1,1 eq), 3h, rt, (vi) $\mathrm{H}_{2}, 10 \%$ Pd/C, DMF, overnight; (vii) linker (1eq), DIEA (3eq), BOP (1.1eq), DMF, 2h, rt: (viii) TFA/ $\mathrm{H}_{2} \mathrm{O} / \mathrm{EDT}(92.5 / 5 / 2.5), 6 \mathrm{~h}$, rt, (ix) 3-isocyanatopropyl triethoxysilane (ICPTES), DIEA(4eq), DMF, 2h, rt.

(i) Fmoc-AA-OH anchoring on 2 chloro chloro trityl resin

2-chloro chloro trityl resin $(1.6 \mathrm{mmol} / \mathrm{g}$, 1eq) was swelled for 10 minutes in DCM. After DCM removal, the resin was placed in a solid-phase peptide synthesis flask fitted with a sintered glass. Fmoc-AA-OH (3 eq) was anchored to the resin in the presence of DIEA (6 eq.) in anhydrous DCM. After standard washing steps using the following solvents $(2 \times \mathrm{DCM} 5$ min, $2 \times$ DMF 5 min and 1× DCM 5 min), Fmoc-AA-Cltrityl-resin was dried under vacuum for $12 \mathrm{~h}$. Fmoc titration was performed.

For Fmoc-Gly-Cltrityl-resin a loading of $0.93 \mathrm{mmol} / \mathrm{g}$ was obtained.

For Fmoc-BAla-Cltrityl-resin a loading of $0.89 \mathrm{mmol} / \mathrm{g}$ was obtained.

(ii) Standard Fmoc deprotection ${ }^{[3]}$

Fmoc-peptidyl-resin was placed in a solid-phase peptide synthesis flask fitted with a glass sintered. Fmoc group was removed by three successive DMF-piperidine $(80: 20 ; \mathrm{v} / \mathrm{v})$ treatments $\left(10^{\prime}, 5^{\prime}, 10^{\prime}\right)$. Between each treatment, solution was filtered off and replaced by a new one.

(iii) Standard protected aminoacid coupling step ${ }^{[3]}$

The appropriate Fmoc-protected amino acid (3 eq.) was dissolved in DMF (75\% of reactor volume) in presence of BOP (3 eq.) and DIEA (6 eq.) for 10 min. This solution was then added to the free $\mathrm{N}$-terminus peptidyl resin and placed under stirring at room temperature. Effectiveness of the reaction was monitored by disappearance of primary amino group at the $\mathrm{N}$ terminus of the growing peptide. This was checked by a negative Kaiser test ${ }^{[1]}$ or TNBS test. ${ }^{[2]}$

The peptidyl resin Fmoc-Asp(OtBu)-DPhe-Lys(Z)-Arg(Pbf)-Gly-resin was synthesized using standard deprotection and coupling cycles (ii) and (iii). Amino acids used were successively Fmoc-Arg(Pbf)-OH, Fmoc-Lys(Z)-OH, Fmoc-(D)Phe-OH, Fmoc-Asp(OtBu)-OH.

The peptidyl resine Boc- $\beta A l a_{5}$-resin and Boc- $\beta A A_{3} a_{3}-A l a\left(C_{3}\right)-\beta A l a-r e s i n$ were synthesized using standard deprotection and coupling cycles (ii) and (iii). Amino acids used were Fmoc$\beta$ Ala-OH and Fmoc-3,3,3 (L,D) trifluoro alanine.

(iv) Selective mild acidic of peptidyl resin.

Resin was treated with TFE/AcOH/DCM (20/10/70, v/v/v) solution at room temperature for 1 $\mathrm{h}$, then filtered, and finally washed twice with cleavage solution. Filtrate was evaporated to dryness under vacuum, and crude peptide was precipitated by addition of cold diethylether (400 mL). Protected peptide was thus obtained by filtration. 
After solubilization of crude peptide in water/acetonitrile $1 / 1 \mathrm{v} / \mathrm{v}$ solution and freeze drying, partially deprotected peptide was analyzed by LC/MS.

Protected peptide $\mathrm{H}-\mathrm{Asp}(\mathrm{OtBu})-\mathrm{DPhe}-\mathrm{Lys}(\mathrm{Z})-\mathrm{Arg}(\mathrm{Pbf})-\mathrm{Gly}-\mathrm{OH}$ was obtained with $89 \%$ yield and used without any purification.

Protected Peptide $\mathrm{Boc}_{-} \mathrm{BAla}_{4}-\mathrm{OH}$ was obtained with $92 \%$ yield and used without any purification.

Protected Peptide Boc- $\beta$ Ala-Ala $\left(\mathrm{CF}_{3}\right)-\beta \mathrm{Ala}_{2}-\mathrm{OH}$ was obtained with $88 \%$ yield and used without any purification.

\section{(v) Head-to-tail cyclization}

Protected peptide $\mathrm{H}-\mathrm{Asp}(\mathrm{OtBu})-\mathrm{DPhe}-\mathrm{Lys}(\mathrm{Z})-\mathrm{Arg}(\mathrm{Pbf})-\mathrm{Gly}-\mathrm{OH}(1.0 \mathrm{~g}, 0.94 \mathrm{mmol}$, 1eq.), was placed in $2 \mathrm{~L}$ round-bottom flask with $1000 \mathrm{~mL}$ of DMF yielding a $10^{-2} \mathrm{M}$ solution. To this solution are successively added DIEA $(0.487 \mathrm{~mL}, 2.82 \mathrm{mmol}$, 3eq.) and BOP $(457 \mathrm{mg}$, $1.034 \mathrm{mmol}, 1.1 \mathrm{eq}$.). After 2 hours stirring at room temperature, the yellow solution was concentrated under high-vacuum, precipitated by added $\mathrm{Et}_{2} \mathrm{O}$, then triturated with a saturated aqueous sodium bicarbonate $(300 \mathrm{~mL})$, filtrated then washed successively with $1 \mathrm{M}$ potassium hydrogen sulfate solution $(3 \times 100 \mathrm{~mL})$ and with $\mathrm{H}_{2} \mathrm{O}$ solution. The crude compound was then dissolved in water/acetonitrile solution $1 / 1 \mathrm{v} / \mathrm{v}$ and freeze-dried to yield $960 \mathrm{mg}$ of protected cyclic peptide. (Yield 98\%)

\section{(vi) Benzyloxycarbonyl (Z) removal in solution}

$960 \mathrm{mg}(0.92 \mathrm{mmol})$ of cyclic peptide were poured into a $500 \mathrm{~mL}$ round-bottom flask fitted with a hole-stopper suitable for bubbling. After solubilization in DMF (100 mL), palladium on carbon (10\% wt, $206 \mathrm{mg}$ ) catalyst was added to the solution. The heterogeneous mixture was submitted to hydrogen bubbling under strong magnetic stirring for 24 hours at room temperature. Catalyst was filtered out on celite and the filtrate was evaporated under vacuum

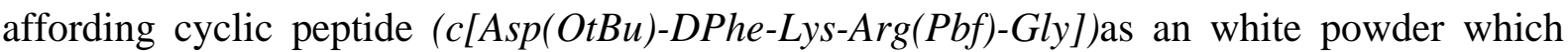
was purified by preparative HPLC using the following conditions. Non-linear gradient was run from [100:0, (0.1\% aqueous TFA: 0,1\% TFA in ACN)] to 60:40 in $10 \mathrm{~min}$, then 60:40 to 30:70 in $30 \mathrm{~min}$ with UV detection at $214 \mathrm{~nm}$. After lyophilisation protected compound was obtained with ( $80 \%$ yield).

\section{(vii) Standard protected aminoacid coupling step in solution}

Crude peptide $(0.36 \mathrm{mmol}$, 1eq.), was placed in $250 \mathrm{~mL}$ round-bottom flask with $30 \mathrm{~mL}$ of DMF. To this solution are successively added DIEA $(0.54 \mathrm{mmol}, 1.5 \mathrm{eq}$.$) and a solution of$ linker $(0.36 \mathrm{mmol}$; 1eq) mixed with DIEA (0.54 mmol, 1.5 eq. $)$ and BOP $(0.40 \mathrm{mmol}, 1.1 \mathrm{eq}$.$) .$ After 2 hours stirring at room temperature, the solution was concentrated under high-vacuum, precipitated by added $\mathrm{Et}_{2} \mathrm{O}$ then triturated with a saturated aqueous sodium bicarbonate $(300$ $\mathrm{mL})$, filtrated then washed successively with $1 \mathrm{M}$ potassium hydrogen sulfate solution $(3 \times 100$ $\mathrm{mL}$ ) and $\mathrm{H}_{2} \mathrm{O}$ solution. The crude compound was then dissolved in water/acetonitrile solution $1 / 1 \mathrm{v} / \mathrm{v}$ and freeze-dried.

Crude protected-cyclopeptide $c\left[A s p(O t B u)-D P h e-L y s\left(B o c-\beta A_{5}\right)-A r g(P b f)-G l y\right]$ was obtained $(0.33 \mathrm{mmol})$ and used without further purification. (yield $92 \%)$

Crude protected-cyclopeptide $c\left[A s p(O t B u)\right.$-DPhe-Lys $\left(B o c-\beta A l a-A l a\left(C F_{3}\right)-\beta A l a_{2}\right)-A r g(P b f)-$ Gly] was obtained $(0.32 \mathrm{mmol})$ and used without further purification. (yield $89 \%)$ 
(viii) Acido labile protecting group removal

Protected cyclic peptide was poured into a $250 \mathrm{~mL}$ round-bottom flask then was treated with TFA/ $\mathrm{H}_{2} \mathrm{O} / \mathrm{EDT}(92.5 / 5 / 2.5$, v/v/v) solution at room temperature for 2 hours. Mixture was evaporated to dryness under vacuum, and crude peptide was precipitated by addition of cold diethylether $(250 \mathrm{~mL})$ and purified by preparative HPLC.

Cyclopeptide $c$ [Asp-DPhe-Lys(H-BAla 4$)$-Arg-Gly] was purified by preparative HPLC using the following conditions. Non-linear gradient was run from [100:0, $(0.1 \%$ aqueous TFA: $0.1 \%$ TFA in ACN)] to 100:0 in $7 \mathrm{~min}$, then 100:0 to 90:10 in $5 \mathrm{~min}$, and 90:10 to 60:40 in $30 \mathrm{~min}$ with UV detection at $214 \mathrm{~nm}$. After lyophilisation $0.20 \mathrm{mmol}$ of deprotected compound was obtained (61\% yield).

Cyclopeptide $c\left[A s p-D P h e-L y s\left(H-\beta A l a-A l a\left(C F_{3}\right)-\beta A l a_{2}\right)-A r g-G l y\right]$ was purified by preparative HPLC using the following conditions. Non-linear gradient was run from [100:0, $(0.1 \%$ aqueous TFA: 0.1\% TFA in ACN)] to 100:0 in $7 \mathrm{~min}$, then 100:0 to 90:10 in $5 \mathrm{~min}$, and 90:10 to $60: 40$ in $30 \mathrm{~min}$ with UV detection at $214 \mathrm{~nm}$. After lyophilisation $0.28 \mathrm{mmol}$ of deprotected compound was obtained ( $88 \%$ yield).

(ix) silylation with ICTPES

To the solution of cyclic peptide $(0.1 \mathrm{mmol})$ in $100 \mu \mathrm{L}$ of DMF was added DIEA (4 eq.) and 3-isocyanatopropyltrimethoxysilane (1.2 eq.). The reaction mixture was allowed to stir for 2 hours at room temperature. After $120 \mathrm{~min}$, reaction was monitored by HPLC. Ether $(30 \mathrm{~mL})$ was poured into the reaction mixture to cause precipitation. The precipitate was suspended in ether again and recollected. This procedure was repeated three times to remove TICPS and DIEA. All crude compounds were analyzed by analytical HPLC, LC/MS and NMR and used without further purification.

Hybrid peptide 2 (97\% yield)

Hybrid peptide 3 (94\% yield)

Synthesis of hybrid peptide 3 : cyclic[Lys[(EtO $)_{3} \mathrm{Si}\left(\mathrm{CH}_{2}\right)_{3} \mathrm{NHCO}-[\beta \mathrm{Ala}]-3,3,3$ trifluoro Ala-ßBAla 2 ]Arg-Gly-Asp-(D)Phe].

Synthesis of $\mathbf{3}$ proceeded in the same way than $\mathbf{2}$ except that 3,3,3 trifluoro alanine introduced to replace two beta alanine residues within the linker between peptide core and trialkoxysilyl moiety.

Fmoc-3,3,3 (L,D) trifluoro alanine was used as building block.

\section{Protocol 2}

(i) Fmoc-Arg(pbg)-OH (3eq), DIEA (6 eq), DCM anh., 6 h, rt; SPPS: (ii): deprotection: Pip/DMF (20/80) and (iii) coupling: Fmoc-AA-OH (3eq), BOP (3eq), DIEA (6 eq), DMF, rt; (iv) TFE/AcOH/DCM (20/10/70, v/v/v), 1h, rt. (v) DIEA (3eq), BOP (1.1eq), 3h, rt (vii) linker (1eq), DIEA (3eq), BOP (1.1eq), DMF, 2h, rt: (viii) TFA/ $\mathrm{H}_{2} \mathrm{O} / \mathrm{EDT}(92.5 / 5 / 2.5)$, 1h, rt, (ix) 3-isocyanatopropyl triethoxysilane (ICPTES), DIEA (4eq), DMF, 2h, rt.

(i) Fmoc-Arg(Pbf)-OH anchoring on 2 chloro chloro trityl resin see synthesis of compound 2 
For Fmoc-Arg(pbf)-Cltrityl-resin a loading of $0.85 \mathrm{mmol} / \mathrm{g}$ was obtained.

(ii) Standard Fmoc deprotection ${ }^{[3]}$ see synthesis of compound 2

(iii) Standard protected aminoacid coupling step ${ }^{[3]}$ see synthesis of compound $\mathbf{2}$

The peptidyl resin Fmoc-Ala-Thr(tBu)-Trp(Boc)-Leu-Pro-Pro-Arg(pbf)-resin was synthesized using standard deprotection and coupling cycles (ii) and (iii). Amino acids used were successively Fmoc-Pro-OH, Fmoc-Leu-OH, Fmoc-Trp(Boc)-OH, Fmoc-Thr(tBu)-OH, FmocAla-OH.

Boc- $\beta$ Ala $_{4}$-resin and Boc- $\beta \mathrm{Ala}_{2}-\mathrm{Phe}(\mathrm{F})-\beta$ Ala-resin were synthesized using standard deprotection and coupling cycles (ii) and (iii). Amino acids used were Fmoc- $\beta$ Ala-OH and Fmoc-3F (L) phenylalanine.

(iv) Selective mild acidic of peptidyl resin. see synthesis of compound $\mathbf{2}$

Protected peptide H-Ala-Thr(tBu)-Trp(Boc)-Leu-Pro-Pro-Arg(pbf)-OH was purified by preparative HPLC using the following conditions. Non-linear gradient was run from [100:0, (0.1\% aqueous TFA: 0.1\% TFA in ACN)] to 55:45 in $10 \mathrm{~min}$, then 55:45 to 35:65 in $20 \mathrm{~min}$ with UV detection at $214 \mathrm{~nm}$. After lyophilisation protected compound was obtained with (80\% yield).

Protected peptid $\mathrm{Boc}_{-} \mathrm{BAla}_{4}-\mathrm{OH}$ was obtained with $94 \%$ yield and used without any purification.

Protected peptid Boc- $\beta \mathrm{Ala}_{2}-\mathrm{Phe}(\mathrm{F})-\beta \mathrm{Ala}-\mathrm{OH}$ was obtained with $85 \%$ yield and used without any purification.

(vii) Standard protected aminoacid coupling step in solution. see synthesis of compound 2

Crude protected peptide Boc- $\beta A_{4}-A l a-\operatorname{Th} r(t B u)-\operatorname{Trp}(B o c)$-Leu-Pro-Pro-Arg(pbf)-OH was obtained $(0.34 \mathrm{mmol})$ and used without further purification. (yield $94 \%$ )

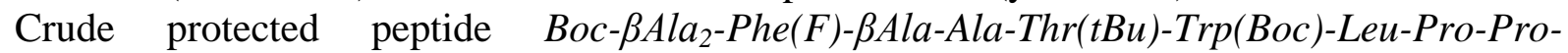
$\operatorname{Arg}(p b f)-O H$ was obtained $(0.32 \mathrm{mmol})$ and used without further purification. (92\% yield)

(viii) Acido labile protecting group removal. see synthesis of compound 2

Crude protected peptide $\mathrm{H}-\beta A_{4}$-Ala-Thr-Trp-Leu-Pro-Pro-Arg-OH was purified by preparative HPLC using the following conditions. Non-linear gradient was run from [100:0, (0.1\% aqueous TFA: $0.1 \%$ TFA in ACN)] to 100:0 in $7 \mathrm{~min}$, then 100:0 to 85:15 in $5 \mathrm{~min}$, and 85:15 to 55:45 in $30 \mathrm{~min}$ with UV detection at $214 \mathrm{~nm}$. After lyophilisation $0.21 \mathrm{mmol}$ of deprotected compound was obtained (62\% yield).

Crude peptide $H$ - $\beta$ Ala-Phe(F)- $\beta$ Ala $_{2}$-Ala-Thr-Trp-Leu-Pro-Pro-Arg-OH was purified by preparative HPLC using the following conditions. Non-linear gradient was run from [100:0, (0.1\% aqueous TFA: $0.1 \%$ TFA in ACN)] to 100:0 in $7 \mathrm{~min}$, then 100:0 to 85:15 in $5 \mathrm{~min}$, and $85: 15$ to $55: 45$ in $30 \mathrm{~min}$ with UV detection at $214 \mathrm{~nm}$. After lyophilisation $0.25 \mathrm{mmol}$ of deprotected compound was obtained ( $78 \%$ yield).

(ix) silylation with ICTPES see synthesis of compound 2 
Hybrid Peptide 4 (92\% yield)

Hybrid Peptide 5 (95\% yield)

Synthesis of hybrid peptide 5 : $(\mathrm{EtO})_{3} \mathrm{Si}\left(\mathrm{CH}_{2}\right)_{3} \mathrm{NHCO}-\beta \mathrm{Ala}$-3fluoro Phe-[ $\left.\beta \mathrm{Ala}\right]_{3}$-AlaThr-Trp-Leu-Pro-Pro-Arg-OH.

Synthesis of 5 proceeded in the same way than 4 except that 3 fluoro phenylalanine was introduced to replace two beta alanine residues within the linker between peptide core and trialkoxysilyl moiety.

Fmoc-3F (L) phenylalanine was used as building block. 
Figure S1. Synthesis of hybrid triethoxysilyl fluorescein 1


Figure S2. LC/MS analysis of fluorescein precursor solution
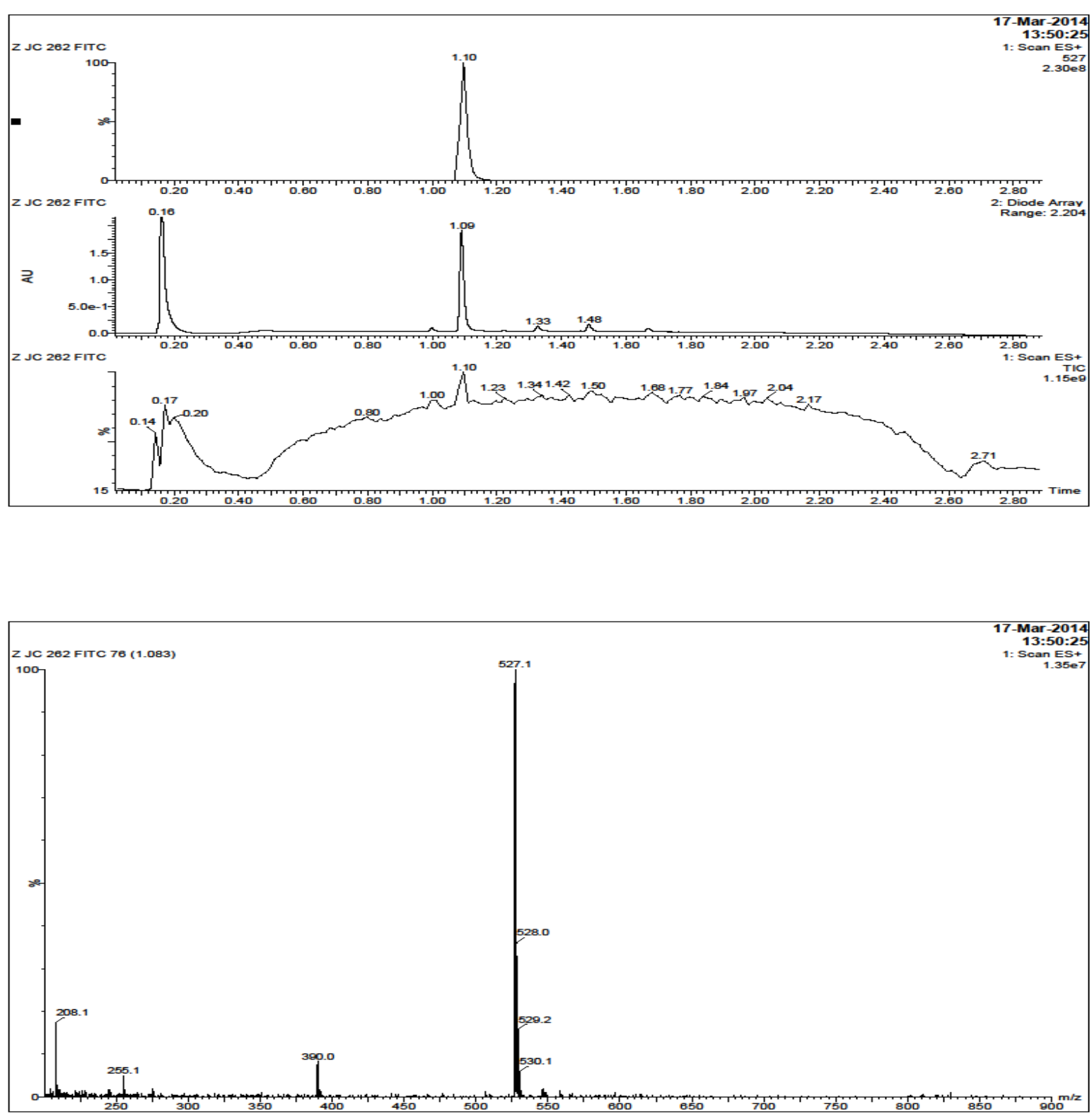
Figure S3. TEM images of unfunctionnalized fluorescent nanoparticles
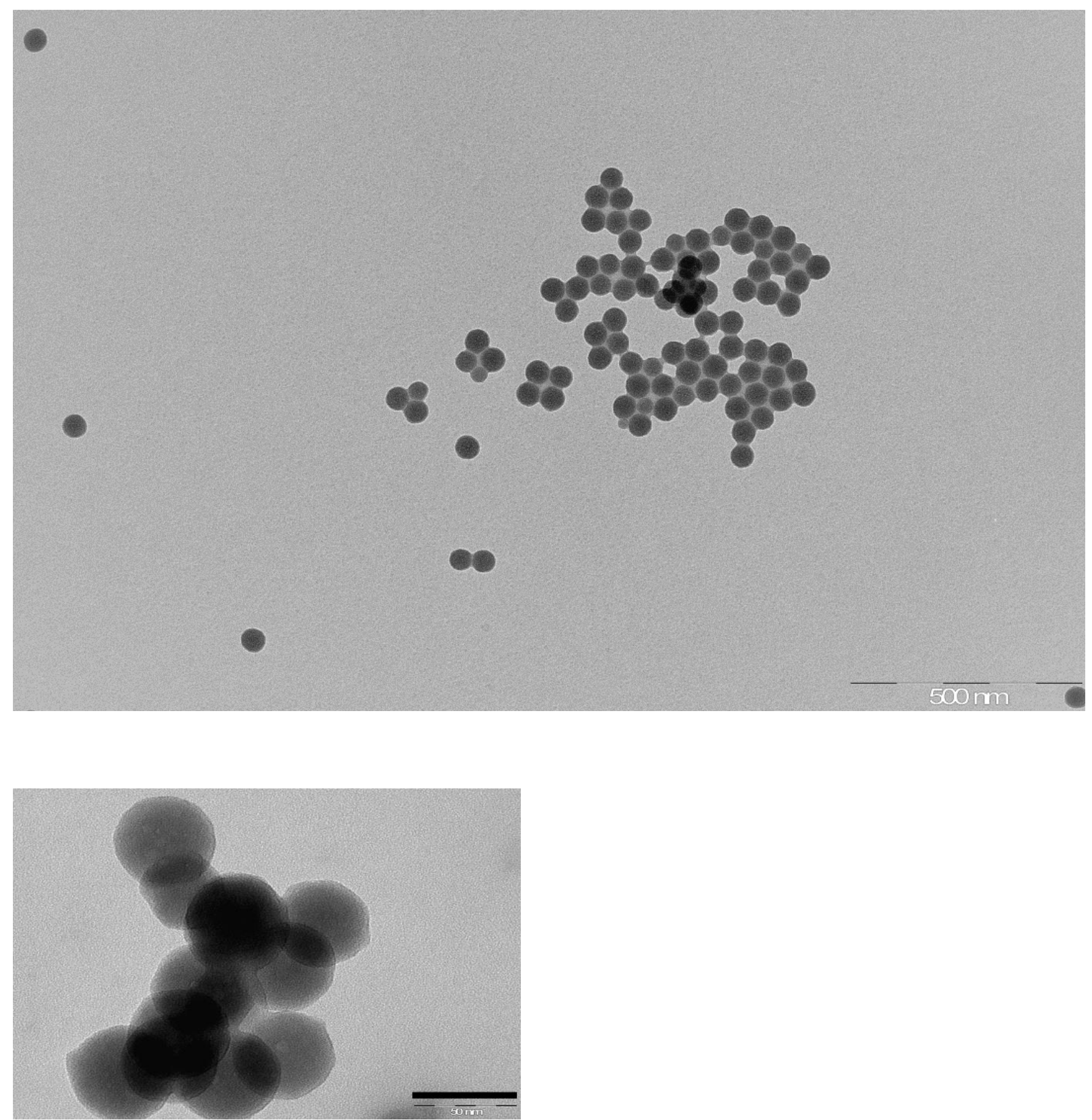
Figure S4. Size distribution of unfunctionnalized fluorescent nanoparticles measured by the DLS technique

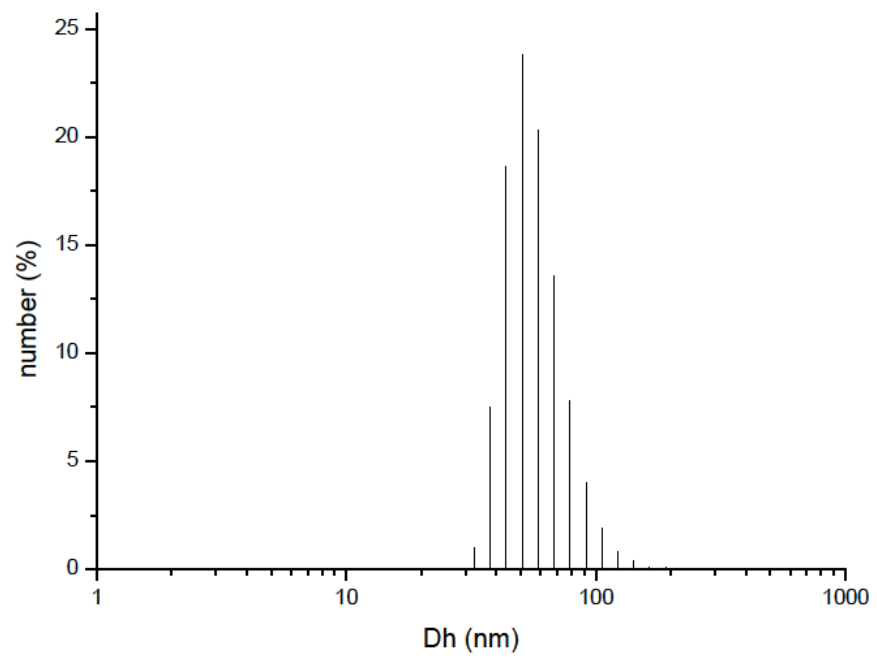

Figure S5. TEM analysis of functionnalized fluorescent nanoparticles $\mathrm{Np}^{25} 5 / 5$

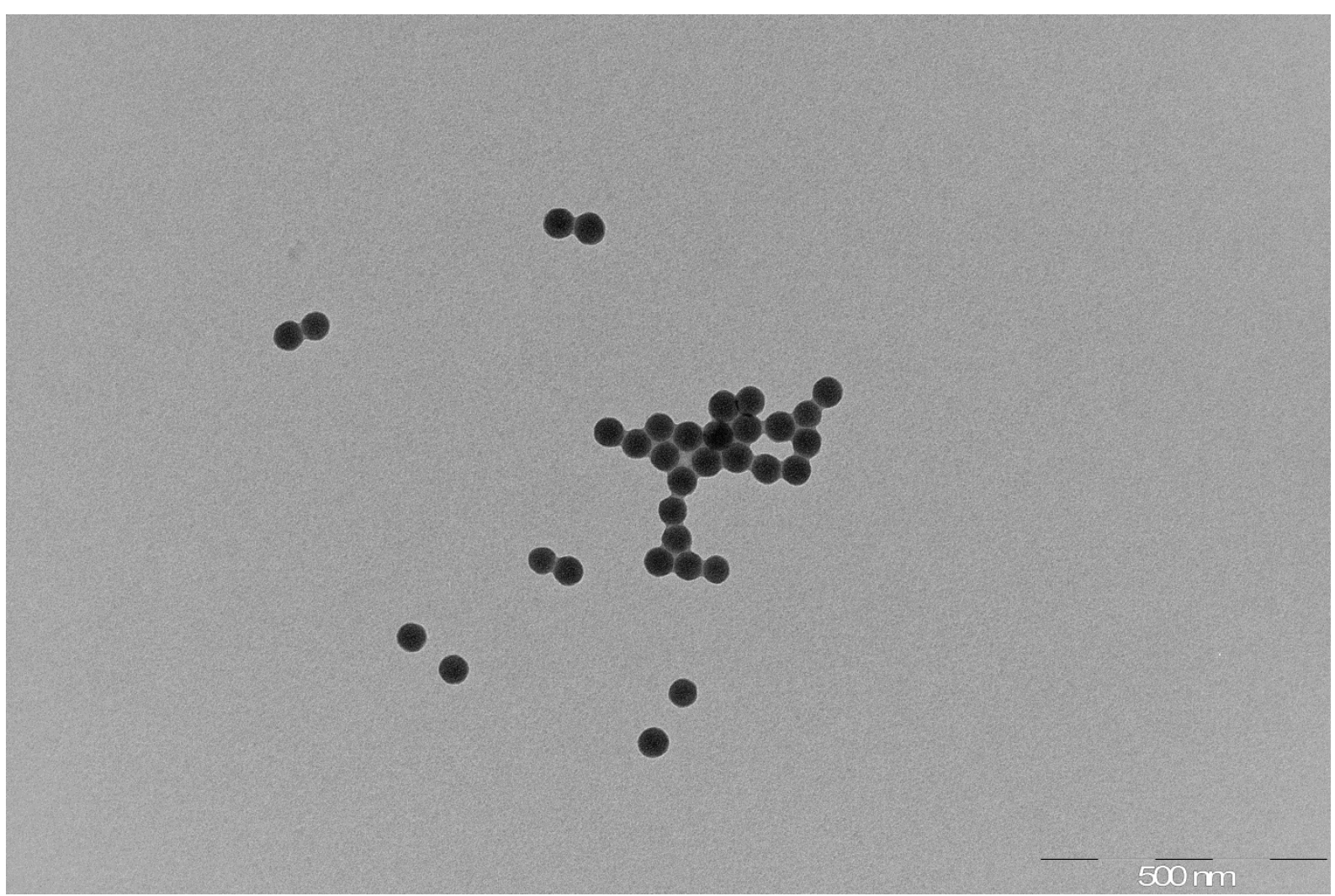


Figure S6. Synthesis of hybrid peptide 2 cyclic[Lys[(EtO) $\left.)_{3} \mathrm{Si}\left(\mathrm{CH}_{2}\right)_{3} \mathrm{NHCO}-[\beta \mathrm{Ala}]_{4}-\right] \mathrm{Arg}-$ Gly-Asp-(D)Phe]




Figure S7. LC/MS analysis of hybrid peptide 2
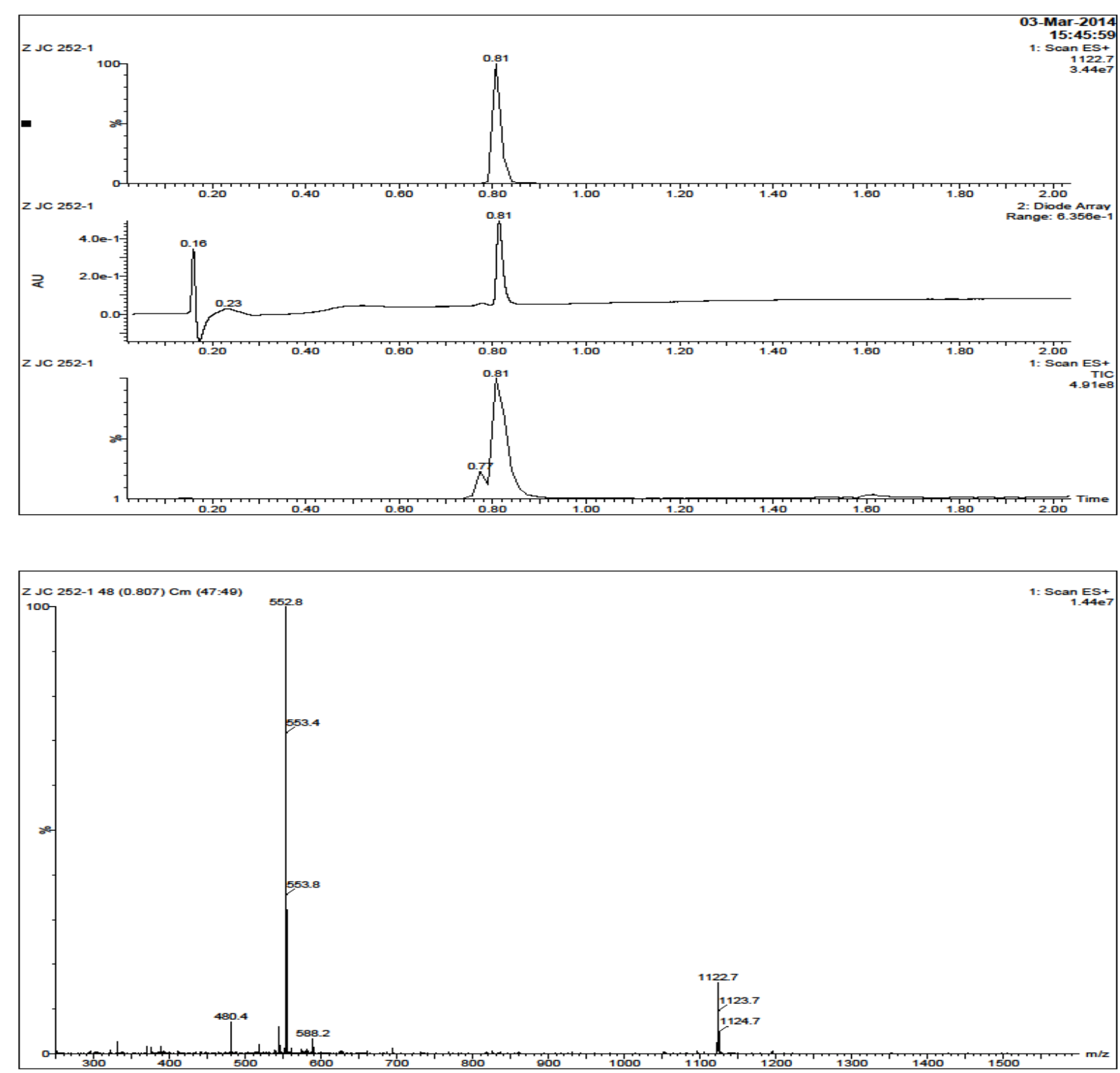
Figure S8. ${ }^{29} \mathrm{Si}$ NMR spectrum of hybrid peptide $\mathbf{2}$

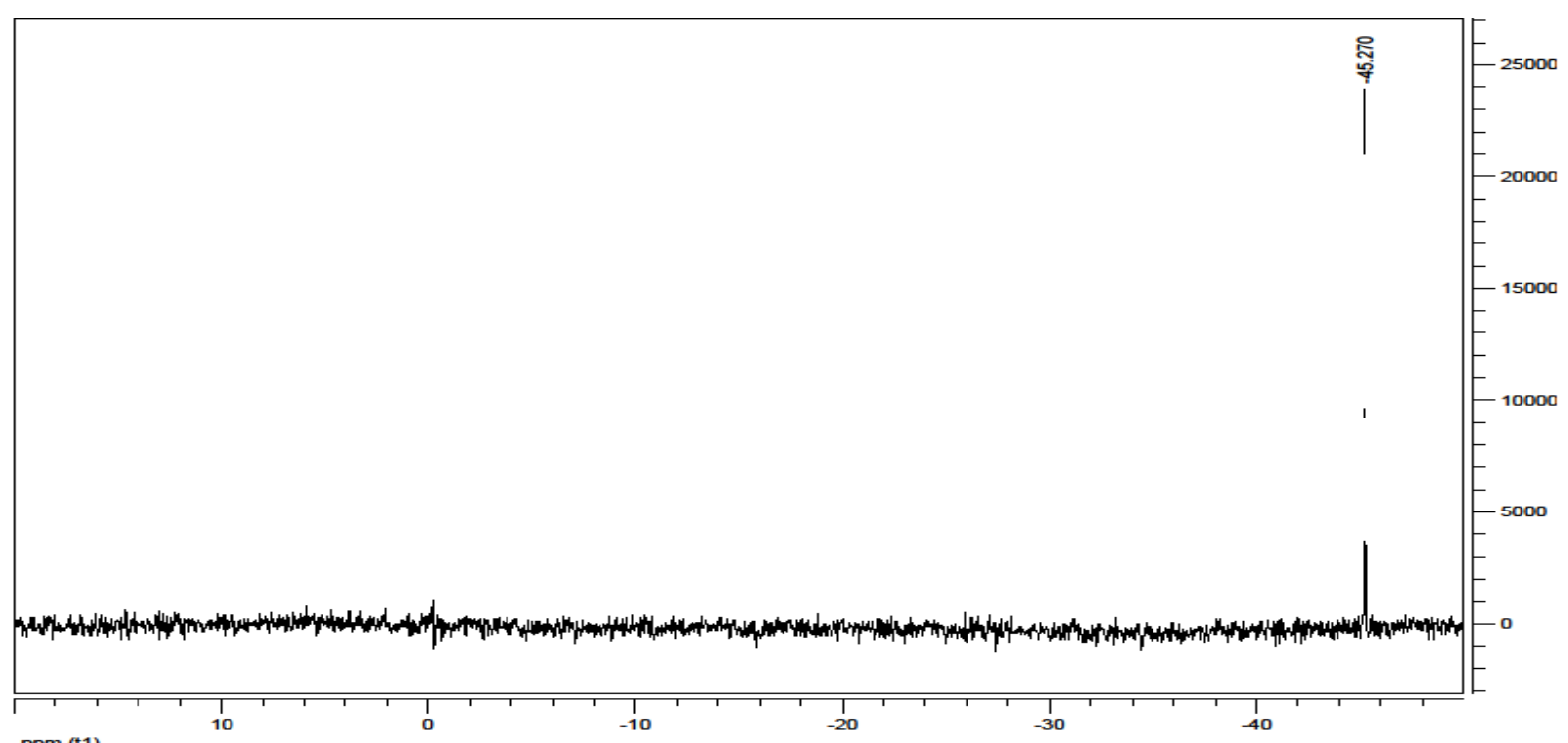

${ }^{29}$ Si NMR: (120 MHz; d-6DMSO) -45.27ppm : Si(OEt) ${ }_{3}$ 
Figure S9. LC/MS analysis of hybrid peptide $\mathbf{3}$

Figure S10. Synthesis of hybrid peptide 4 : $(\mathrm{EtO})_{3} \mathrm{Si}\left(\mathrm{CH}_{2}\right)_{3} \mathrm{NHCO}-[\beta \mathrm{Ala}]_{4}$-Ala-Thr-TrpLeu-Pro-Pro-Arg-OH

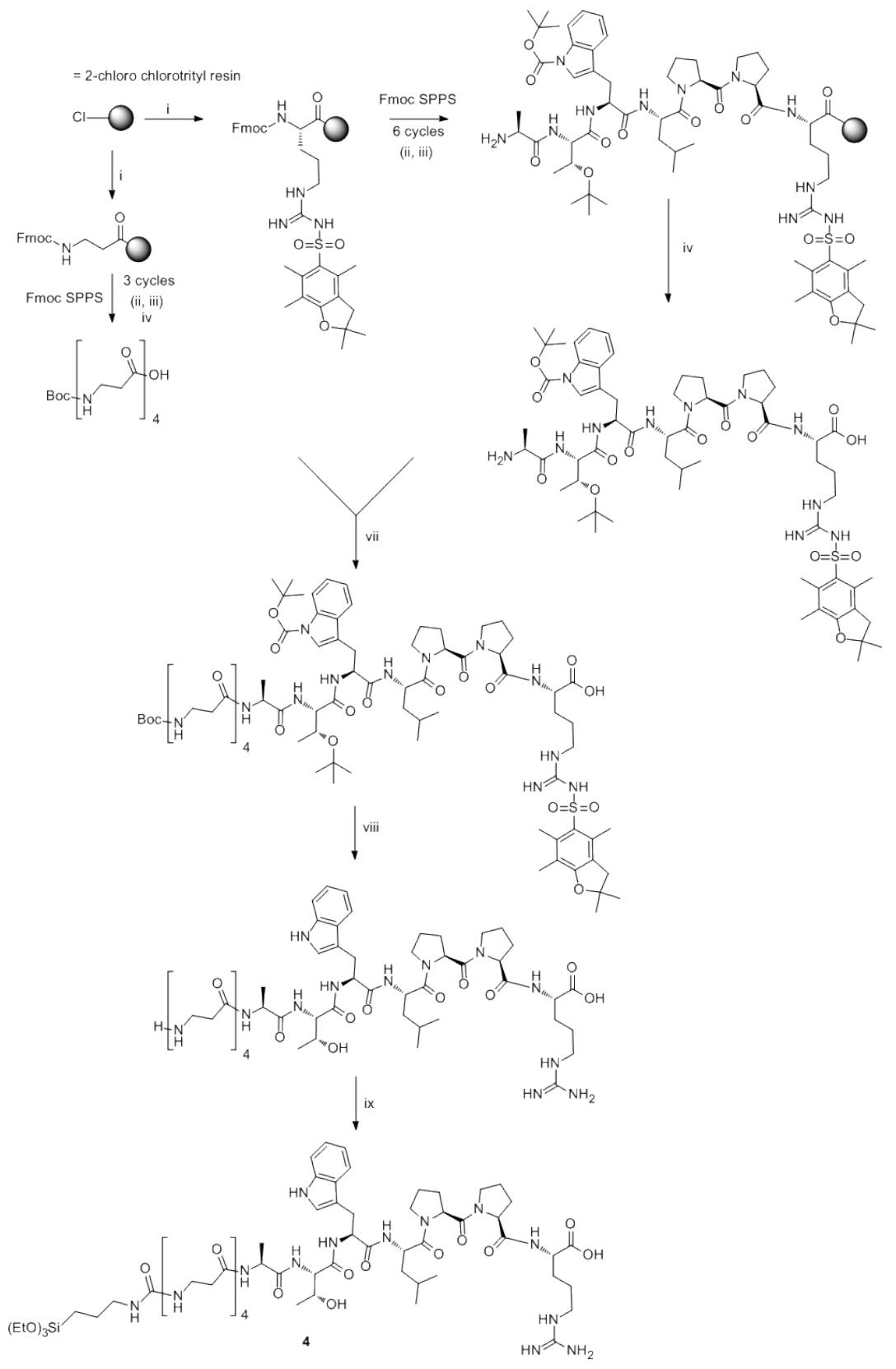


Figure S11. LC/MS analysis of hybrid peptide 4
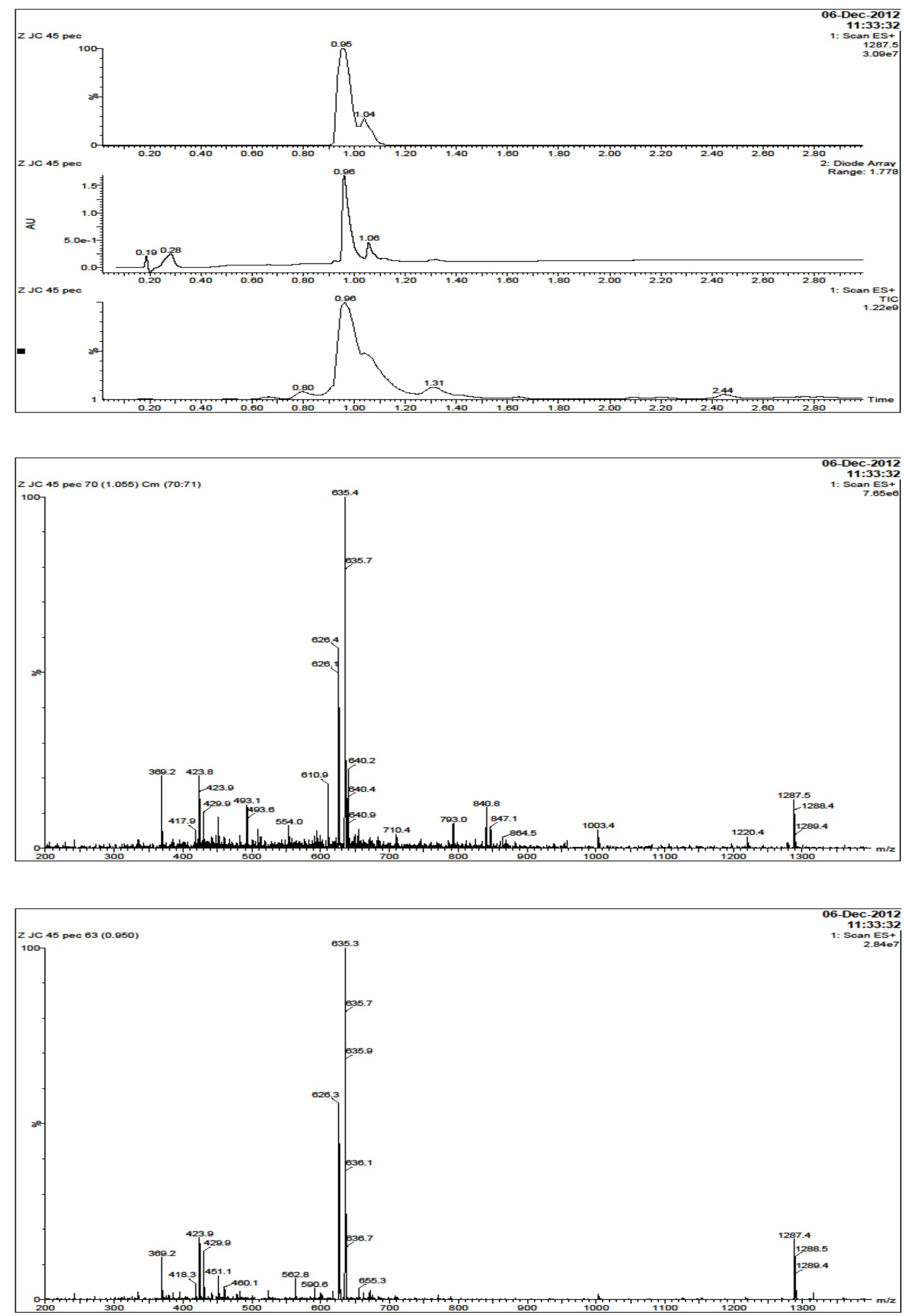
Figure S12. ${ }^{29}$ Si NMR spectrum of hybrid peptide 4

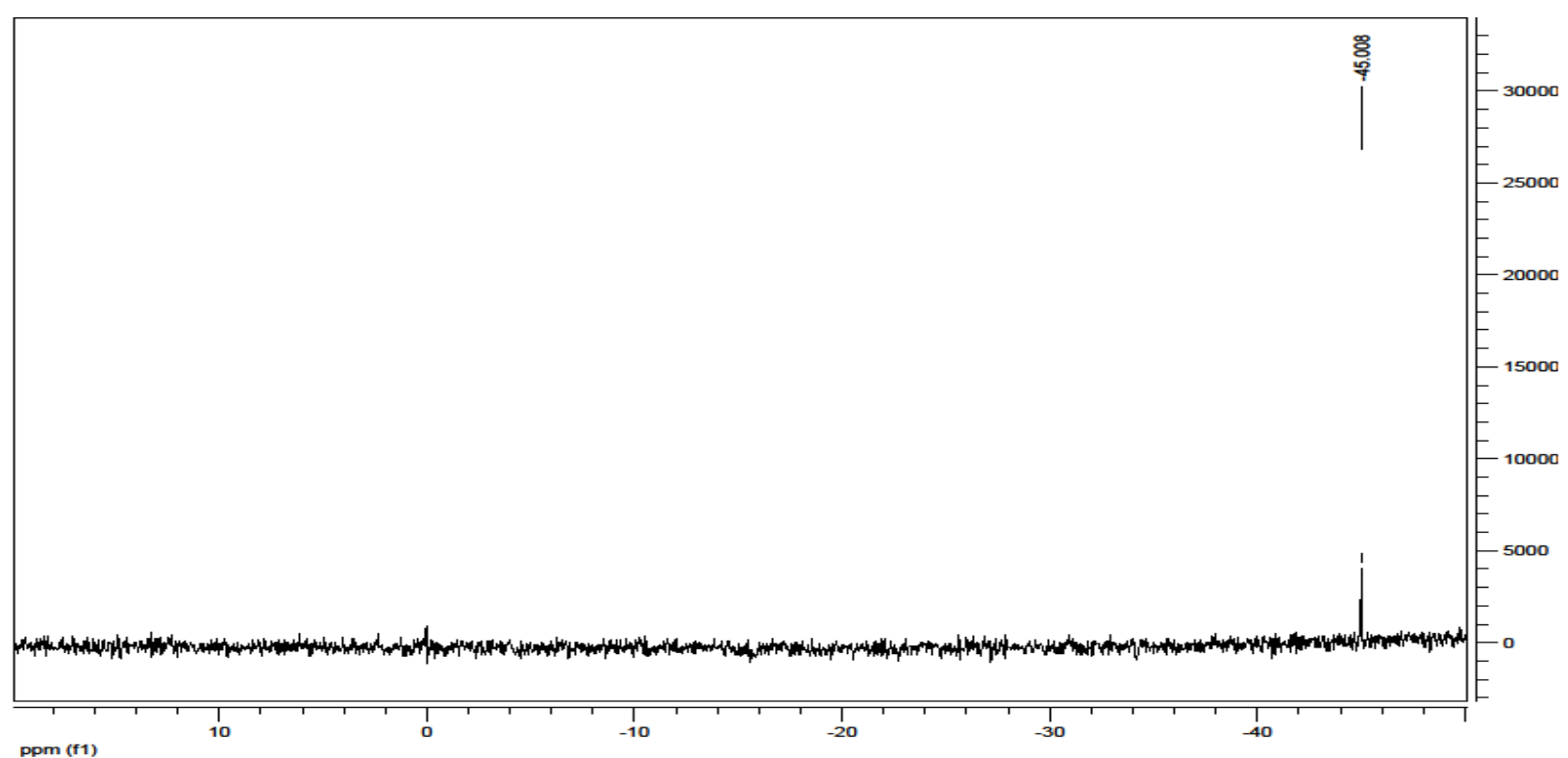

${ }^{29} \mathrm{Si}$ NMR : (120 MHz; d6-DMSO) $-45.00 \mathrm{ppm}: \mathrm{Si}(\mathrm{OEt})_{3}$ 
Figure S13. LC/MS analysis of hybrid peptide 5
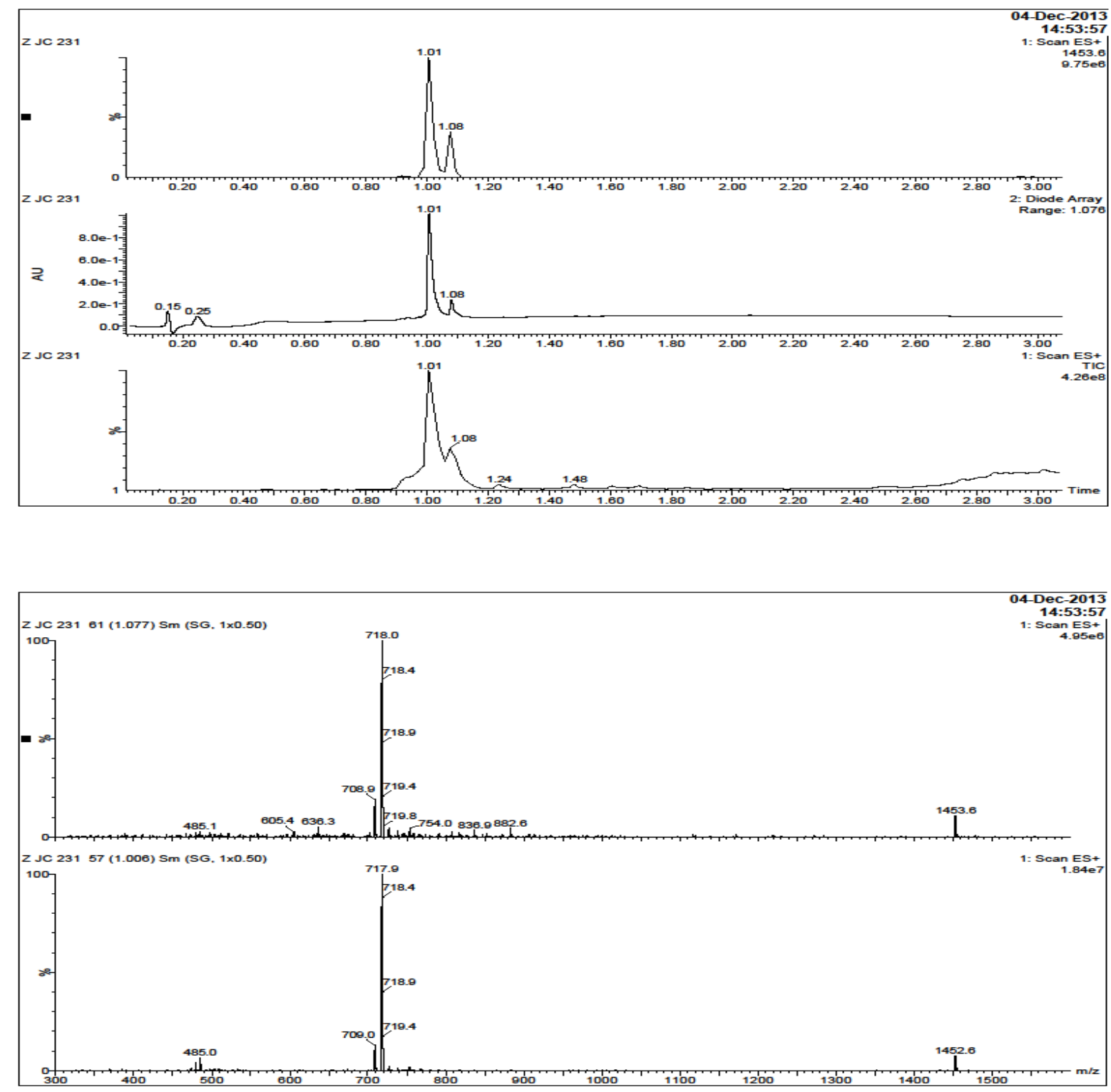
Figure S14. ${ }^{19} \mathrm{~F}$ NMR spectrum of $\mathrm{NP}_{\mathrm{F}}{ }^{10}{ }^{100 / 0}$

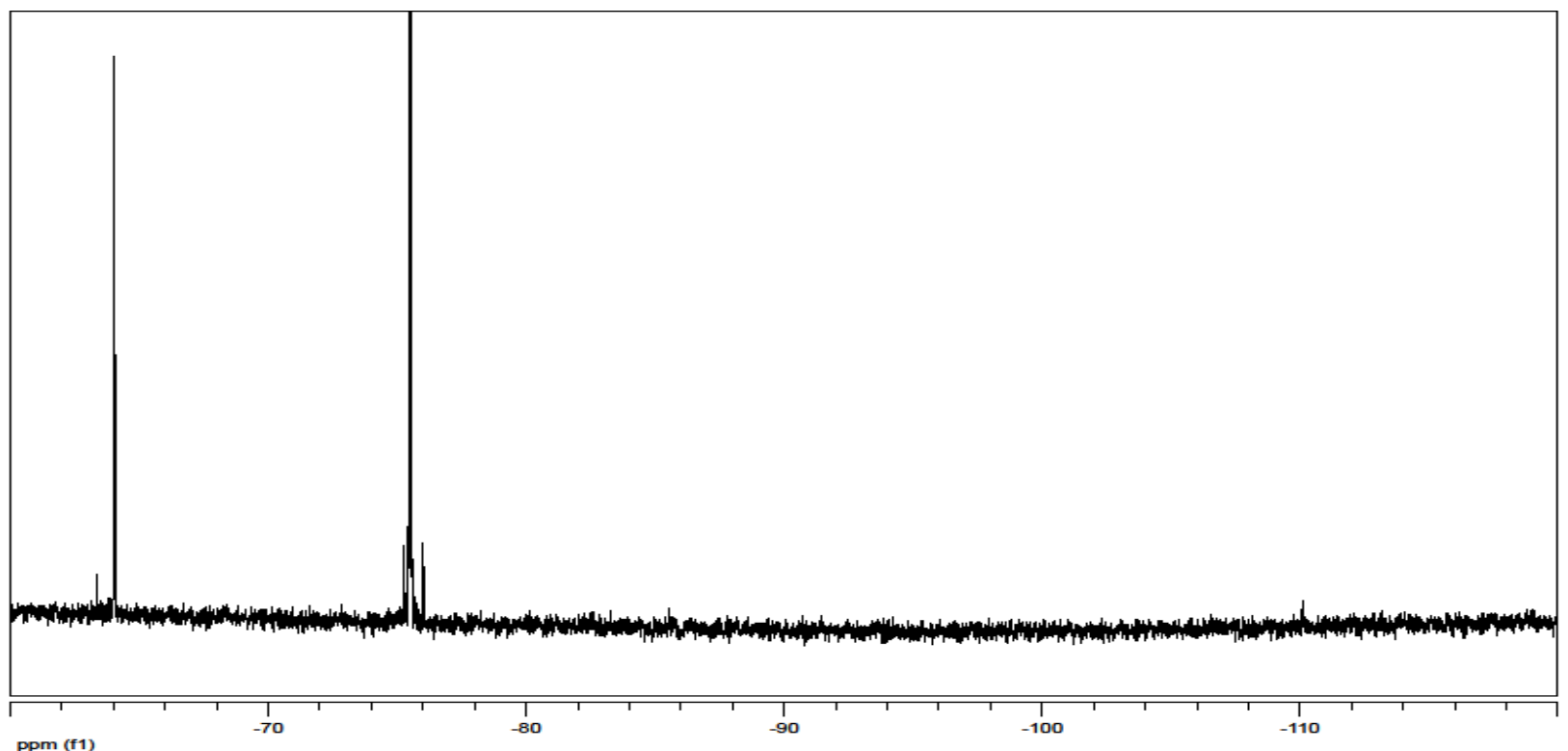

Figure S15. ${ }^{19} \mathrm{~F}$ NMR spectrum of $\mathrm{NP}_{\mathrm{F}}{ }^{10} 75 / 25$

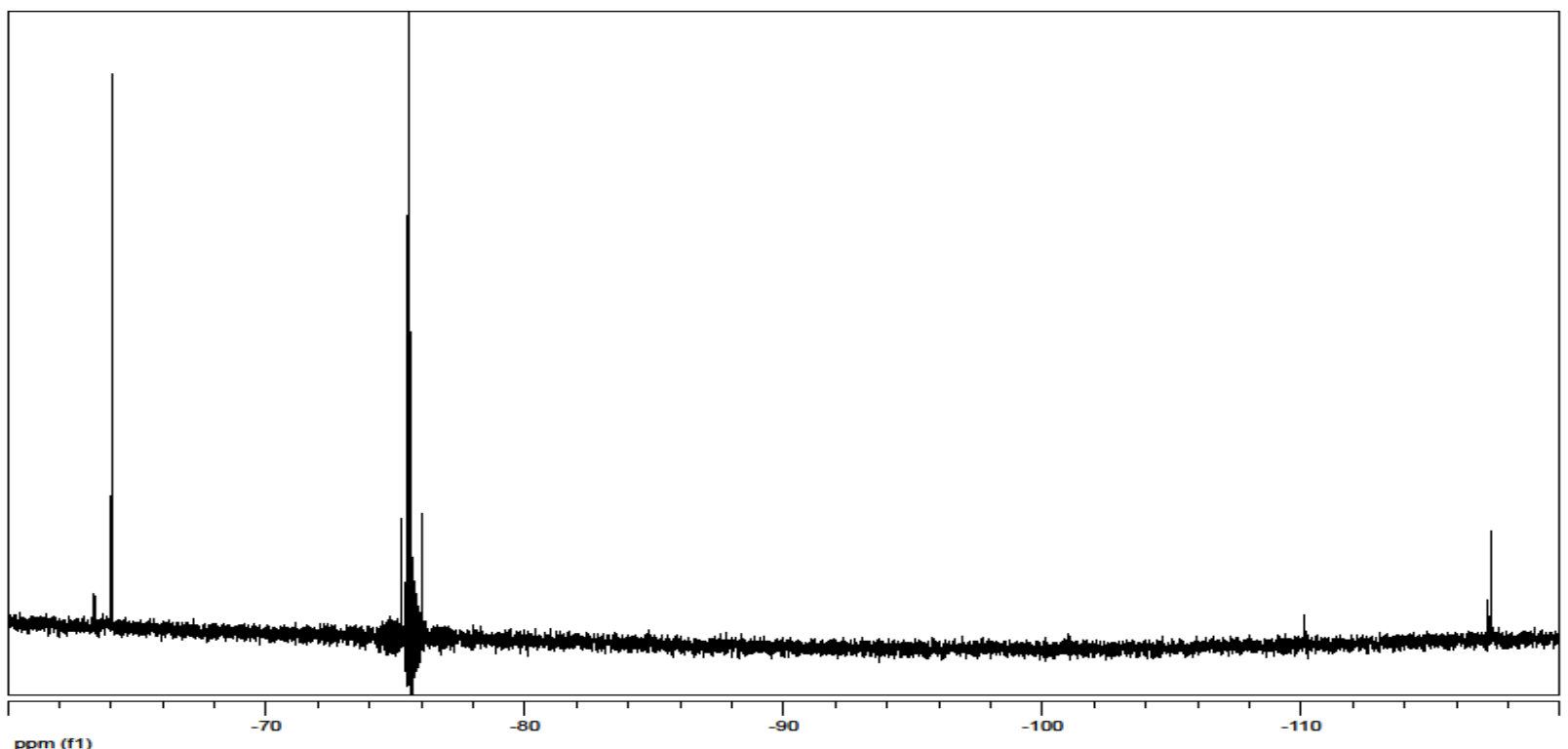


Figure S16. ${ }^{19} \mathrm{~F}$ NMR spectrum of $\mathrm{NP}_{\mathrm{F}}{ }^{10}{ }^{50 / 50}$

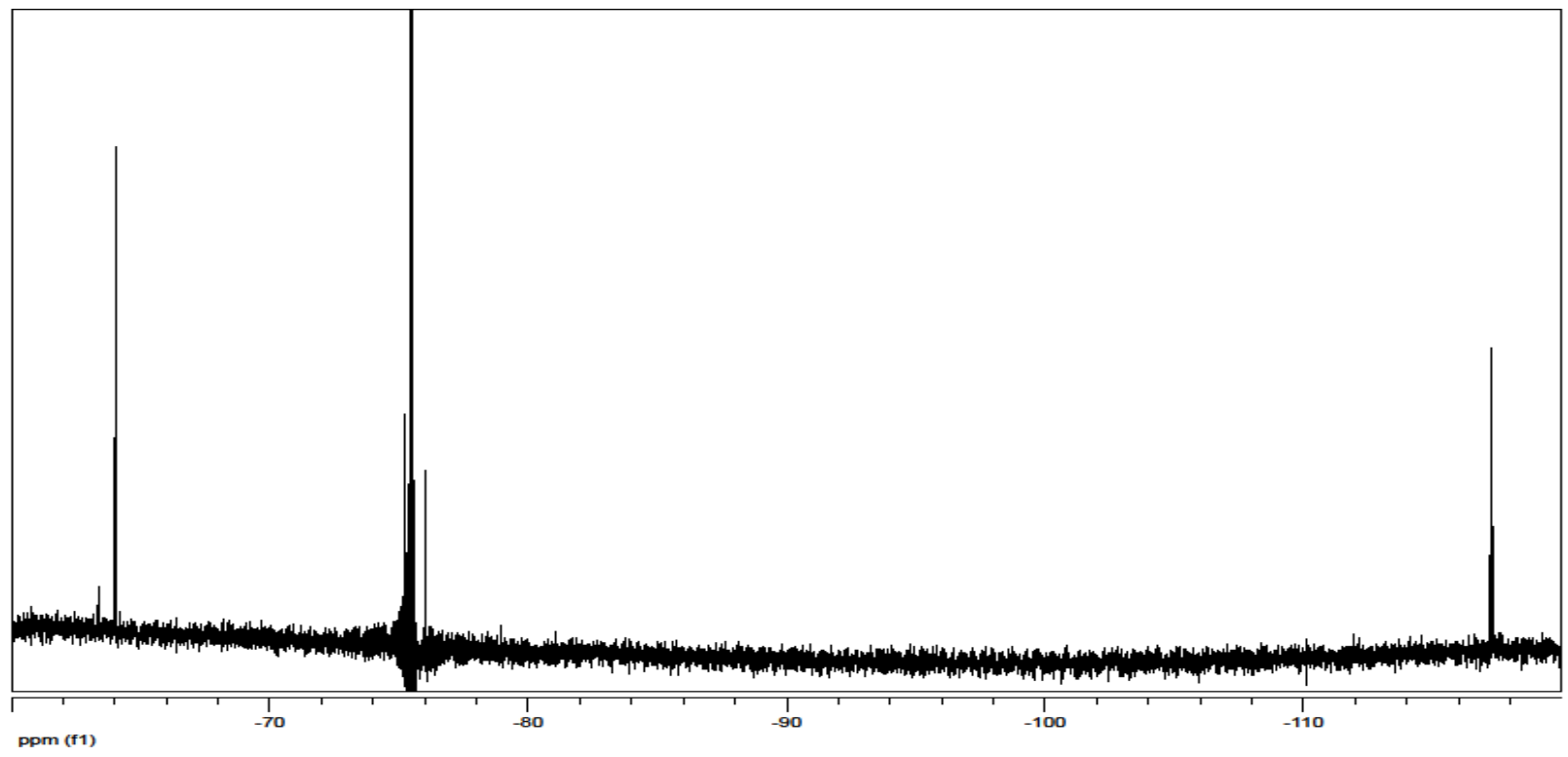

Figure S17. ${ }^{19} \mathrm{~F}$ NMR spectrum of $\mathrm{NP}_{\mathrm{F}}{ }^{10}{ }_{25 / 75}$

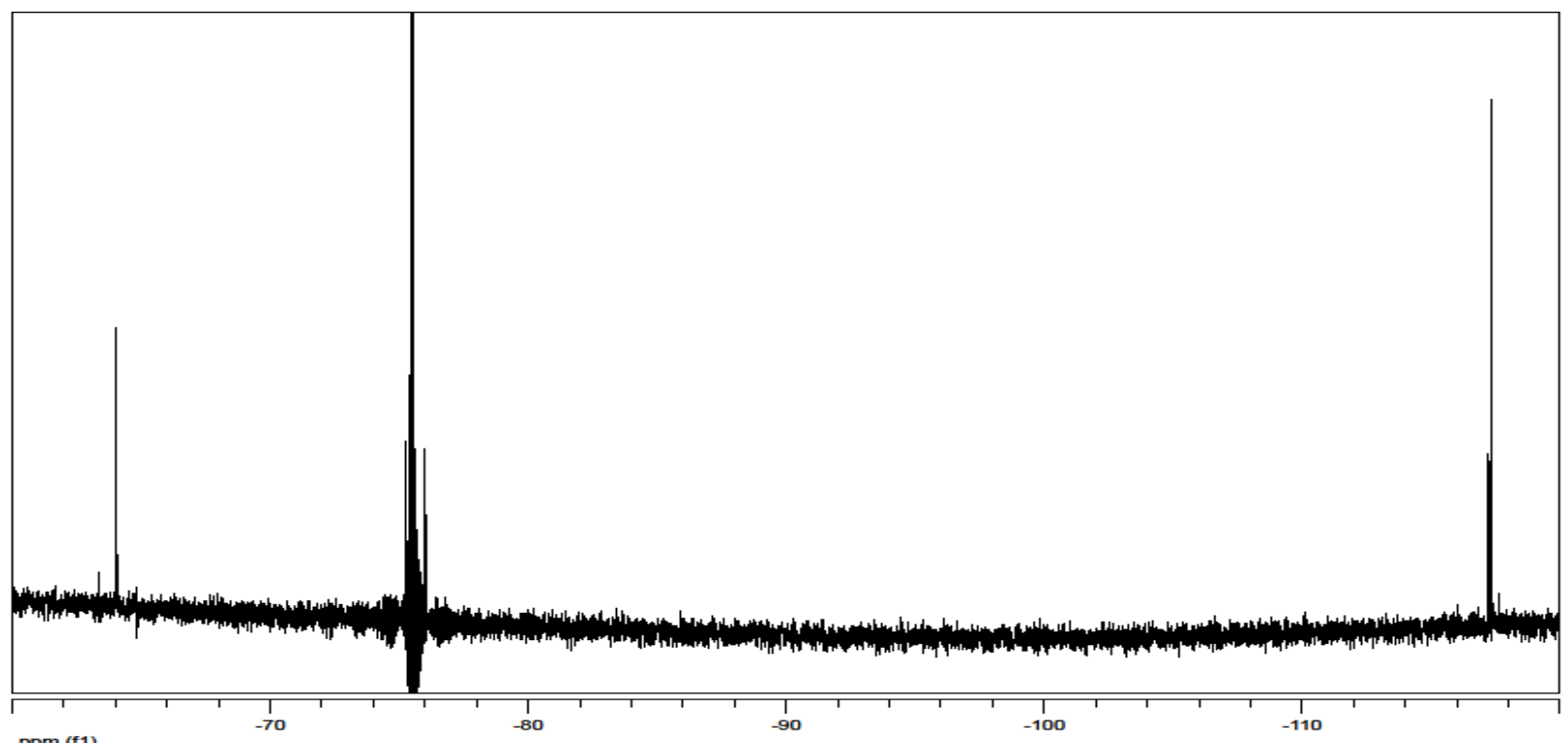


Figure S18. ${ }^{19} \mathrm{~F}$ NMR spectrum of $\mathrm{NP}_{\mathrm{F}}{ }^{10} 0 / 100$

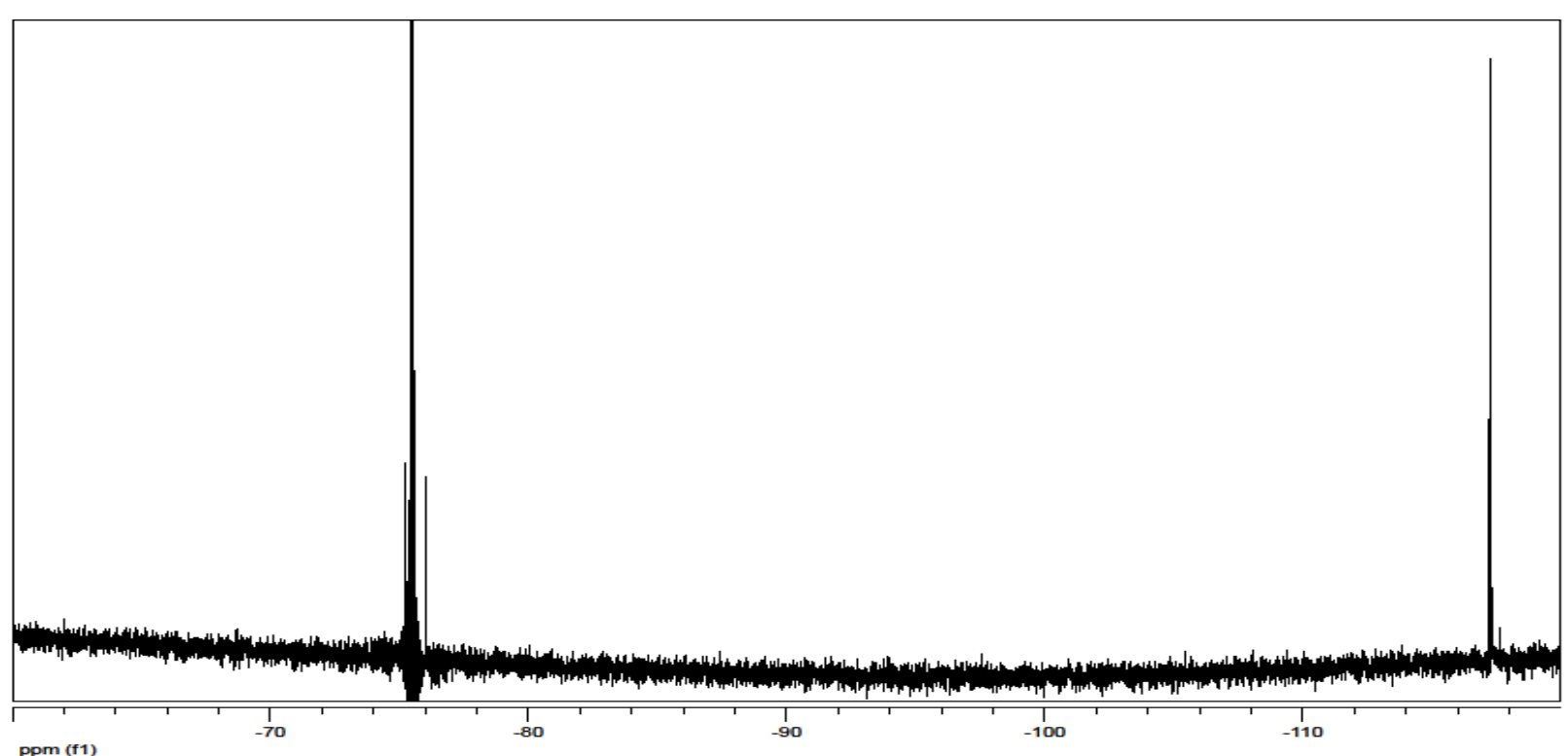


Figure S19. TGA curves of respectively $\mathrm{Np}_{0 / 0}$ and $\mathrm{Np}^{10}{ }_{5 / 5}$

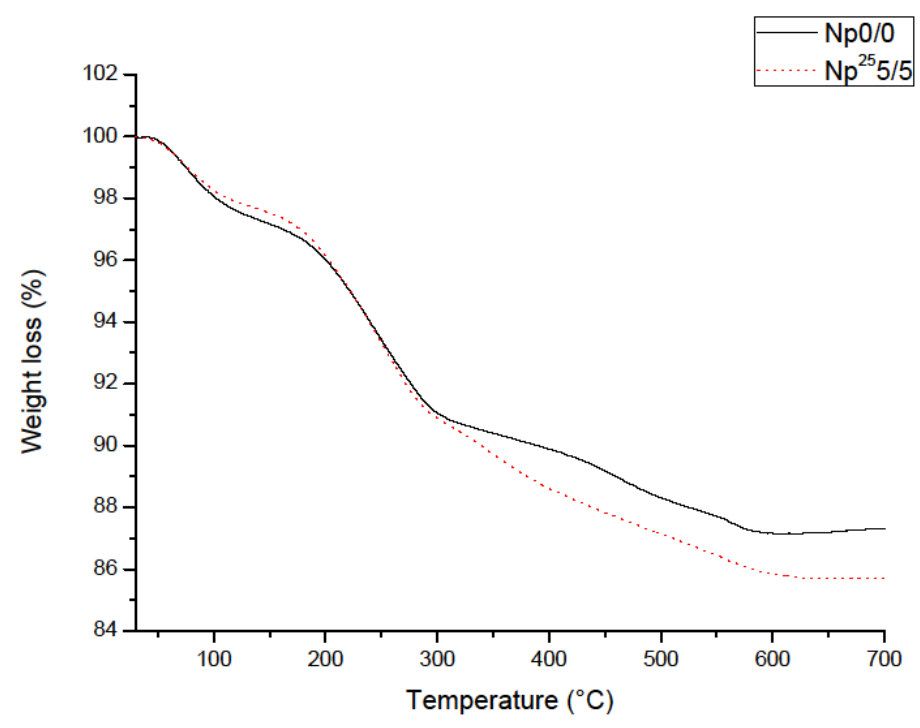


Figure S20. FACS experiments of $\mathrm{NP}^{\mathrm{x}}$ on HUVEC cells line. Influence of loading $\mathrm{x}$. As we can see there is peptide dose effect. $\mathrm{NP}^{10}$ bind more efficiently HUVEC cells lines than $\mathrm{NP}^{1}$ and $\mathrm{NP}^{0.1}$. The Table shows the fluorescence data. Mean FL indicate the mean fluorescent level and CV FL corresponds to the coefficient of variation of the Fluorescence Level.


\section{HUVEC}

\begin{tabular}{|c|c|c|c|}
\hline \multirow[b]{2}{*}{$\begin{array}{l}\% \text { positive } \\
\text { cells }\end{array}$} & $\mathrm{NP}^{0.1}{ }_{100 / 0}$ & $N P^{1}{ }_{100 / 0}$ & $N P^{10}{ }_{100 / 0}$ \\
\hline & $71 \%$ & $94 \%$ & $89 \%$ \\
\hline Mean FL & 142534 & 316866 & 954294 \\
\hline \multirow[t]{2}{*}{ CV FL } & $138 \%$ & $105 \%$ & $135 \%$ \\
\hline & $\mathrm{NP}^{0.1}{ }_{50 / 50}$ & $\mathrm{NP}^{1}{ }_{50 / 50}$ & $\mathrm{NP}^{10}{ }_{50 / 50}$ \\
\hline $\begin{array}{l}\% \text { positive } \\
\text { cells }\end{array}$ & $36 \%$ & $81 \%$ & $89 \%$ \\
\hline Mean FL & 92449 & 222116 & 969696 \\
\hline \multirow[t]{2}{*}{ CV FL } & $334 \%$ & $177 \%$ & $129 \%$ \\
\hline & $N P^{0.1}{ }_{0 / 100}$ & $\mathrm{NP}^{1}{ }_{0 / 100}$ & $N P^{10}{ }_{0 / 100}$ \\
\hline $\begin{array}{c}\% \text { positive } \\
\text { cells }\end{array}$ & $18 \%$ & $57 \%$ & $69 \%$ \\
\hline Mean FL & 41821 & 100591 & 160160 \\
\hline CV FL & $335 \%$ & $201 \%$ & $180 \%$ \\
\hline
\end{tabular}


Figure S21. FACS experiments of $\mathrm{NP}_{\mathrm{F}}{ }^{10}$ on MDA-MB-231 and $\mathrm{H} 358$ cells line. Influence of the ratio y/z. The Table shows the fluorescence data. Mean FL indicate the mean fluorescent level and CV FL corresponds to the coefficient of variation of the Fluorescence Level.

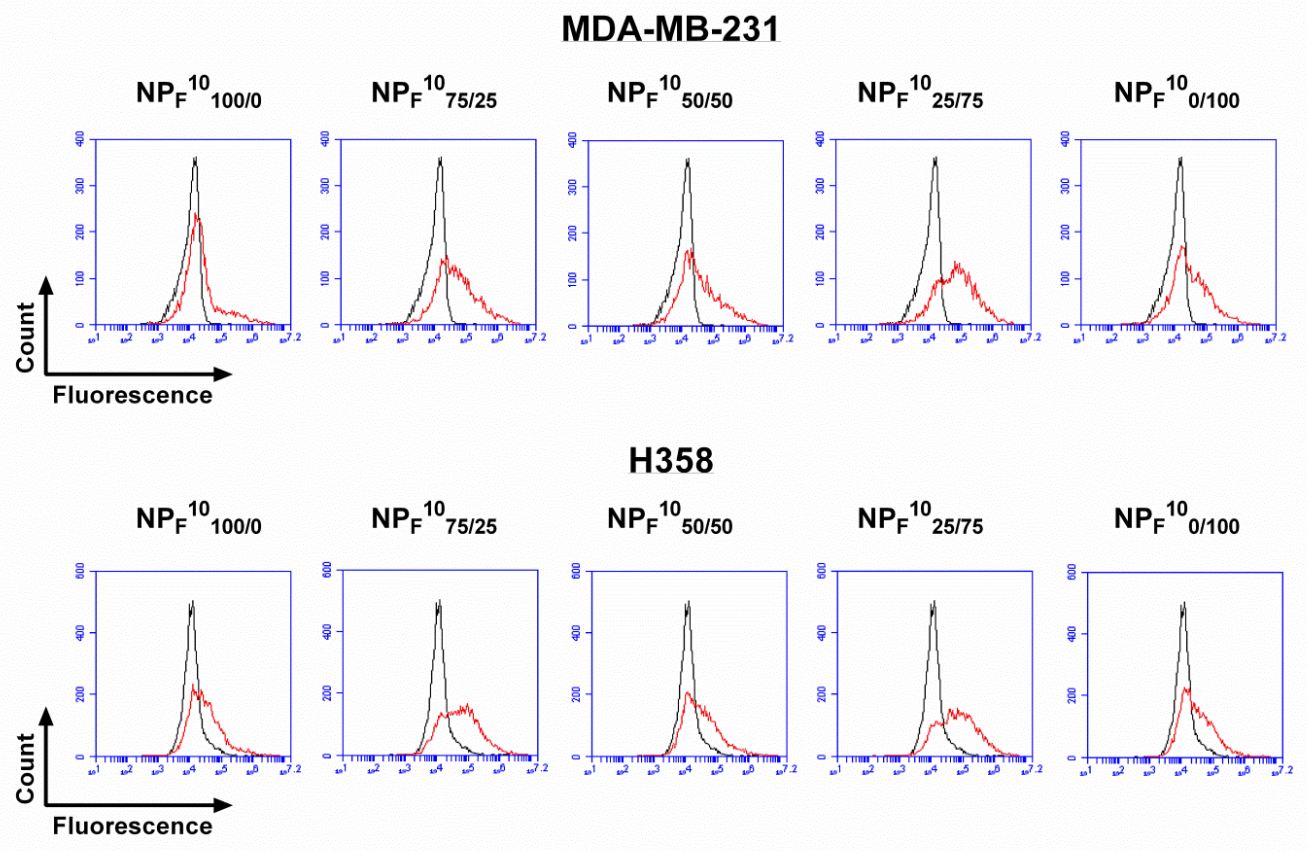

\begin{tabular}{|c|c|c|c|c|c|}
\hline \multicolumn{6}{|c|}{ MDA-MB-231 } \\
\hline & $\mathrm{NP}_{\mathrm{F}}{ }^{10}{ }_{100 / 0}$ & $\mathrm{NP}_{\mathrm{F}}{ }^{10}{ }_{75 / 25}$ & $\mathrm{NP}_{\mathrm{F}}{ }^{10}{ }_{50 / 50}$ & $\mathrm{NP}_{\mathrm{F}}{ }^{10}{ }_{25 / 75}$ & $\mathrm{NP}_{\mathrm{F}}{ }^{10}{ }_{0 / 100}$ \\
\hline $\begin{array}{c}\% \text { positive } \\
\text { cells }\end{array}$ & $19 \%$ & $48 \%$ & $37 \%$ & $61 \%$ & $36 \%$ \\
\hline Mean FL & 97429 & 170125 & 134232 & 202413 & 90508 \\
\hline CV FL & $413 \%$ & $278 \%$ & $282 \%$ & $260 \%$ & $287 \%$ \\
\hline
\end{tabular}

H358

\begin{tabular}{cccccc} 
& $\mathbf{N P}_{\mathbf{F}}{ }^{10}{ }_{100 / 0}$ & $\mathbf{N P}_{\mathbf{F}}{ }^{10}{ }^{75 / 25}$ & $\mathbf{N P}_{\mathbf{F}}{ }^{10}{ }^{50 / 50}$ & $\mathbf{N P}_{\mathbf{F}}{ }^{10}{ }^{25 / 75}$ & $\mathbf{N P}_{\mathbf{F}}{ }^{10}{ }_{0 / 100}$ \\
\cline { 2 - 6 } $\begin{array}{c}\text { \% positive } \\
\text { cells }\end{array}$ & $7 \%$ & $17 \%$ & $9 \%$ & $23 \%$ & $7 \%$ \\
Mean FL & 104491 & 161264 & 118599 & 215710 & 91011 \\
CV FL & $376 \%$ & $259 \%$ & $363 \%$ & $245 \%$ & $359 \%$
\end{tabular}


Figure S22. Temporal evolution of hydrodynamic size of nanoparticles measured in cell media (PBS) by the DLS technique. A $(\mathrm{t}=0), \mathrm{B}(\mathrm{t}=40 \mathrm{~min}), \mathrm{C}(\mathrm{t}=1.5 \mathrm{~h})$ and $\mathrm{D}(\mathrm{t}=3 \mathrm{~h})$

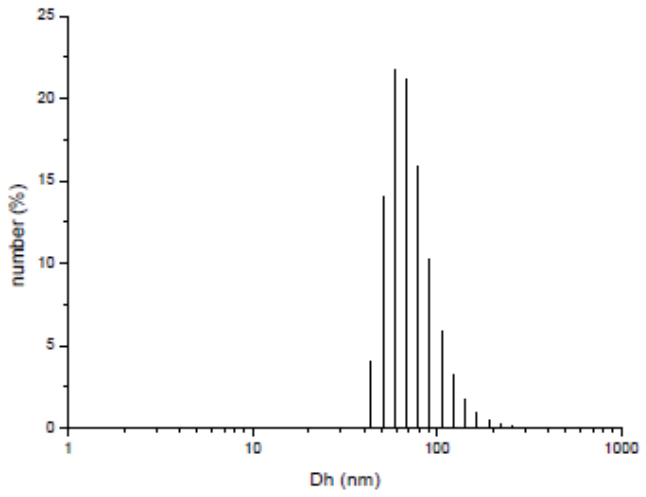

A

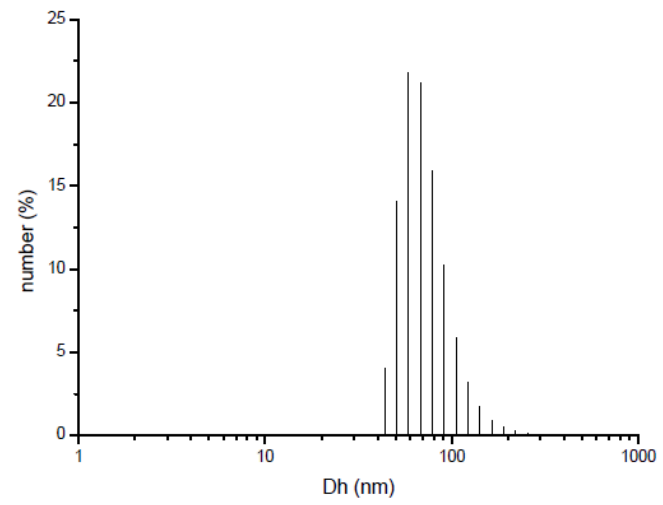

C

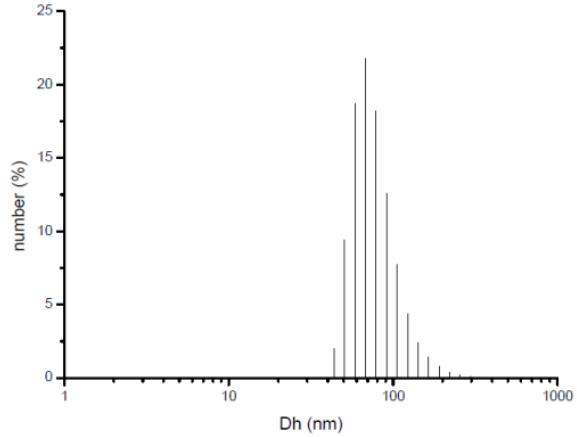

B

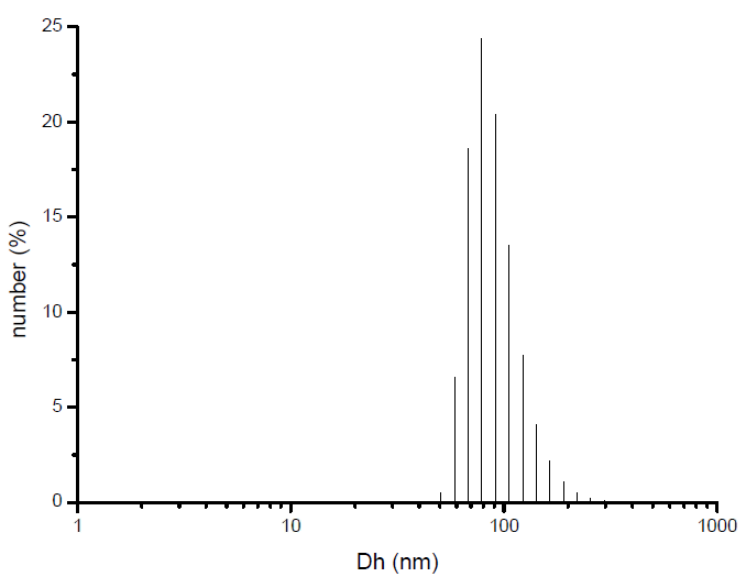

D 
Table S1. Characterization of multifunctional NPs

\begin{tabular}{|c|c|c|c|c|c|c|}
\hline NP & $\begin{array}{c}\text { Loading } \\
(\mu \mathrm{mol} / \mathrm{g})\end{array}$ & $\begin{array}{l}\text { Ratio } \\
(\mathbf{2 / 4})\end{array}$ & $\% \mathrm{~N}[\mathrm{a}]$ & $\% \mathrm{C}[\mathrm{a}]$ & $\mathrm{TGA}\left[800^{\circ} \mathrm{C}\right][\mathrm{b}]$ & $\begin{array}{l}\text { DLS(PDI) [c] } \\
(\mathrm{nm})\end{array}$ \\
\hline $\mathrm{NP}_{0 / 0}$ & 0 & $0 / 0$ & 0.91 & 5.39 & 12.5 & $79(0.12)$ \\
\hline $\mathrm{NP}^{10}{ }_{10 / 0}$ & \multirow{5}{*}{10} & $10 / 0$ & 1.96 & 7.02 & 15.7 & $75(0.15)$ \\
\hline $\mathrm{NP}^{10}{ }_{7.5 / 2.5}$ & & $7.5 / 2.5$ & 1.92 & 7.32 & 16.5 & $77(0.12)$ \\
\hline $\mathrm{NP}^{10}{ }_{5 / 5}$ & & $5 / 5$ & 1.80 & 7.13 & 14.3 & $76(0.12)$ \\
\hline $\mathrm{NP}^{10}{ }_{2.5 / 7.5}$ & & $2.5 / 7.5$ & 1.71 & 7.55 & 15.6 & $80(0.14)$ \\
\hline $\mathrm{NP}^{10}{ }_{0 / 10}$ & & $0 / 10$ & 1.93 & 7.18 & 17.8 & $77(0.13)$ \\
\hline $\mathrm{NP}_{10 / 0}^{1}$ & \multirow{5}{*}{1} & $10 / 0$ & 0.98 & 5.89 & 12.5 & $76(0.12)$ \\
\hline $\mathrm{NP}^{1}{ }_{7.5 / 2.5}$ & & $7.5 / 2.5$ & 0.99 & 5.70 & 12.6 & $81(0.10)$ \\
\hline $\mathrm{NP}_{5 / 5}^{1}$ & & $5 / 5$ & 1.01 & 5.90 & 12.4 & $79(0.14)$ \\
\hline $\mathrm{NP}_{2.5 / 7.5}^{1}$ & & $2.5 / 7.5$ & 0.95 & 5.75 & 12.7 & $80(0.16)$ \\
\hline $\mathrm{NP}_{0 / 10}^{1}$ & & $0 / 10$ & 0.98 & 5.91 & 12.5 & $75(0.16)$ \\
\hline $\mathrm{NP}^{0.1}{ }_{10 / 0}$ & \multirow{5}{*}{0.1} & $10 / 0$ & 0.92 & 5.56 & 12.8 & $75(0.13)$ \\
\hline $\mathrm{NP}^{0.1}{ }_{7.5 / 2.5}$ & & $7.5 / 2.5$ & 0.91 & 5.40 & 12.3 & $79(0.15)$ \\
\hline $\mathrm{NP}^{0.1}{ }_{5 / 5}$ & & $5 / 5$ & 0.90 & 5.39 & 12.4 & $76(0.13)$ \\
\hline $\mathrm{NP}_{2.5 / 7.5}^{0.1}$ & & $2.5 / 7.5$ & 0.92 & 5.43 & 12.5 & $80(0.12)$ \\
\hline $\mathrm{NP}^{0.1}{ }_{0 / 10}$ & & $0 / 10$ & 0.93 & 5.56 & 12.8 & $79(0.13)$ \\
\hline
\end{tabular}

[a] $\% \mathrm{~N}$ and $\% \mathrm{C}$ were determined by elemental analysis

[b] The value in TGA column corresponding to the weight loss at a temperature of $800{ }^{\circ} \mathrm{C}$

[c] PDI : Polydispersity Index

(1) Kaiser, E., et al,. Color test for detection of free terminal amino groups in the solid-phase synthesis of peptides. Anal Biochem. 1970, 34, 595.

(2) Hancock, W.S., Battersby, J.E., A new micro-test for the detection of incomplete coupling reactions in solid-phase peptide synthesis using 2,4,6-trinitrobenzenesulphonic acid. Anal Biochem. 1976, 71, 261.

(3) Amblard, M., Fehrentz, J. A., Martinez, J. \& Subra, G. Methods and Protocols of modern solid phase peptide synthesis. Molecular Biotechnology 2006, 33, 239-254. 